\title{
Bacterivory in Pacific oyster Crassostrea gigas larvae
}

\author{
Philippe Douillet*
}

Oregon State University, Department of Fisheries, Hatfield Marine Science Center, Newport, Oregon 97365, USA

\begin{abstract}
A bacterium (Strain CA2) that enhances survival and growth of larvae of the oyster Crassostrea gigas (Thunberg) was used in a series of experiments to determine the occurrence of bacterivory in straight-hinged bivalve larvae. Size and carbon content of this bacterium was found to be within the range reported for naturally occurring marine bacteria. Unattached, motile, DAPI-stained CA2 cells were readily captured and ingested by oyster larvae and were seen to accumulate in larval digestive systems. Ingestion of ${ }^{14} \mathrm{C}$-labelled bacteria occurred at all bacterial concentrations tested from $1 \times 10^{5}$ to $1 \times 10^{7}$ cells $\mathrm{ml}^{-1}$. Retention of carbon by axenic oyster larvae, fed either ${ }^{14} \mathrm{C}$-labelled live or heat-killed bacteria in 'pulse-chase' feeding experiments, demonstrates the endogenous ability of larvae to digest and assimilate bacterial carbon.
\end{abstract}

\section{INTRODUCTION}

Bacteria constitute a significant portion of the microplankton biomass in the marine environment, and provide important food resources to planktonic food webs (Williams 1981, Ducklow 1983). Heterotrophic protozoans are recognized as the major consumers of bacteria in the marine environment (Haas \& Webb 1979, Caron et al. 1982, Fenchel 1982, Rivier et al. 1985, Sherr \& Sherr 1987), however metazoans of diverse taxonomical groups also feed on bacteria (Zobell \& Feltham 1938, Zhukova 1963, Rivkin et al. 1986). The metabolic requirements of bivalve larvae have been found to be higher than could be met by algal concentrations in natural environments (Bayne 1983, Crisp et al. 1985), and the possibility of bivalve larvae using marine bacteria as a food item has been proposed (Prieur 1981, Crisp et al. 1985), but has not been fully evaluated.

Free-living bacteria have been shown to be far more abundant in epipelagic waters than bacteria associated with particles (Azam \& Hodson 1977, Watson et al. 1977). Studies such as those of Peterson et al. (1978),

\footnotetext{
- Present address: The University of Texas at Austin, Marine Science Institute, PO Box 1267, Port Aransas, Texas 78373, USA
}

Wright et al. (1982), and Fuhrman \& McManus (1984) indicate that the vast majority of bacterioplankton is smaller than $1 \mu \mathrm{m}$ in size. The size spectrum of particles ingested by veliger larvae was reported to exclude particles smaller than $1 \mu \mathrm{m}$ (Riisgard et al. 1980, Sprung 1984), thus veligers would be unable to ingest most naturally occurring marine bacteria (Bayne 1983). In contrast, ingestion of the blue-green algae Synechococcus spp. $(1 \times 0.5 \mu \mathrm{m}$ in size $)$ by 2 and $10 \mathrm{~d}$ old Mercenaria sp. larvae was demonstrated by high-speed video microscopy (Gallager 1988), and evidence of ingestion of bacteria by $17 \mathrm{~d}$ old Mytilus edulis larvae was obtained by scanning electron microscopy of the gut of bacteria-fed veligers (Prieur 1981). The bacterial strains used in this last study were grown in culture media and, unfortunately, the cell size was not reported. Cultured bacteria have been reported to be larger in size than bacteria in natural waters (Peterson et al. 1978, Wilson \& Stevenson 1980, Fuhrman \& McManus 1984). So, the ability of bivalve larvae to ingest bacterioplankton has not yet been determined.

Indirect evidence of ingestion of bacteria by bivalve larvae has to be taken with caution because of experimental artifacts. Accumulation of radioactivity by larval Mytilus galloprovinciallis fed ${ }^{14} \mathrm{C}$-labelled bacteria was documented by Mengus (1978); however, the long exposure period ( $>2 \mathrm{~h}$ ) of larvae to labelled bac- 
teria in that study may have permitted recycling of the label, resulting in indirect uptake of radioactivity rather than direct uptake through bacterivory. Nutrient fluxes between bacteria, bacterivorous protozoa and algae, as described by Berman et al. (1987), may also occur in a system with bacteria, bivalve larvae and algae, particularly considering the significant uptake of dissolved organic matter by bivalve larvae (Manahan \& Richardson 1983). In another study, Crassostrea virginica larvae were found to accumulate ${ }^{3} \mathrm{H}$ activity when exposed to 0.2 to $0.8 \mu \mathrm{m}$ sized, naturally occurring particles labelled with ${ }^{3} \mathrm{H}$-thymidine (Baldwin \& Newell 1991); unfortunately, no abiotic controls were run for adhesion of labelled bacteria to the surface of larvae. Thus, the transfer of radioactive labels from bacteria to bivalve larvae reported above may have been caused by processes other than bacterivory.

In addition, ingestion of bacteria is not conclusive evidence of bacterivory. Mollusc larvae ingest organic and inorganic particles; however, digestible particles are retained for intracellular digestion and nondigestible organic and inorganic particles are passed rapidly to the intestine for defecation (Fretter \& Montgomery 1968, Babinchak \& Ukeles 1979, Bayne 1983, Gallager 1988). Furthermore, while different microbes may be ingested by a grazer, as demonstrated with copepods, only certain microbes are digested and assimilated (Decho \& Castenholz 1986). Despite the above studies that have examined the ability of bivalve larvae to capture and ingest microorganisms, no study has addressed the ability of bivalve larvae to assimilate bacteria.

The objective of this study was to determine if oyster larvae can use bacterioplankton as a carbon source. Two hypotheses were postulated to test the occurrence of this trophic process: (1) oyster larvae are able to capture and ingest a small-sized $(<1 \mu \mathrm{m})$ free-living, motile bacterial strain suspended in the water column; (2) oyster larvae have the endogenous ability to digest bacteria and retain assimilated bacterial carbon.

A direct observation method and an indirect radiotracer method were used to test the first hypothesis. A 'pulse-chase' radiotracer experiment involving the use of axenic oyster larvae was designed to test the second hypothesis. Gut passage time of labelled food was determined in order to ascertain complete depuration of unassimilated ${ }^{14} \mathrm{C}$.

Effects of marine bacteria on algal-fed, axenic larval Crassostrea gigas (Thunberg) have been found to be strain-specific (Douillet 1991). A bacterial strain (CA2) found to enhance survival and growth of oyster larvae (Douillet 1991, Douillet \& Langdon 1993) was used for this investigation in order to eliminate the possibility of adverse bacterial effects during confinement of larvae in feeding chambers. However, larval feeding on natural bacterial populations may produce different results with regards to bacterial ingestion rates, and bacterial carbon assimilation rates by oyster larvae. Size and carbon content of CA2 bacteria were determined to compare the tested bacteria to naturally occurring bacterioplankton.

\section{METHODS}

Size and biovolume of CA2 cells. Suspensions of DAPI-stained CA2 bacteria and fluorescent microspheres, $2 \mu \mathrm{m}$ in diameter (Fluoresbrite YG; Polysciences) were filtered onto $0.2 \mu \mathrm{m}$ black Nuclepore filters. Fluoresbrite microspheres and DAPI-stained cells fluoresce when excited by light at ca $400 \mathrm{~nm}$. The filters were mounted on a slide under high-viscosity, low-fluorescence immersion oil (Resolve; Stephens Scientific) and observed with an epifluorescence microscope (Zeiss Universal). Photographs (Kodak Ektachrome ASA 400) were taken of areas of the filters where bacteria and microspheres were simultaneously in focus, thus reducing halo effects. Photographs were enlarged $(3000 \times)$ and the length and width of 100 bacteria cells were determined with an image-analysis system (Java; Jandel Corporation), which was calibrated by measuring the diameter of fifty $2 \mu \mathrm{m}$ microspheres. Error due to measurement was determined by measuring a single microsphere 20 times. Bacterial biovolume was calculated assuming that the volume of the rods corresponded to the volume of a cylinder with hemispherical ends:

$$
\text { Biovolume of a rod }=\pi r^{2}(L-2 / 3 r)
$$

where $r=$ half of cell width and $L=$ cell length

Carbon content of CA2 cells. CA2 cells grown for $4 \mathrm{~d}$ on marine agar 2216 (Difco) were transferred to $1 / 10$ marine broth 2216 (Difco) enriched with $0.5 \mathrm{~g}$ glucose $\mathrm{l}^{-1}$. After $4 \mathrm{~d}$ of culture, the cells were washed twice in $0.2 \mu \mathrm{m}$ filtered, autoclaved seawater (FSSW) by repeated centrifugation and resuspension, and were resuspended in $18 \mathrm{l}$ of $1 / 10$ marine broth 2216 supplemented with $0.41 \mu \mathrm{mol}$ glucose $\mathrm{l}^{-1}$ and $1.125 \mathrm{ml}$ ethanol $\mathrm{I}^{-1} \cdot{ }^{14} \mathrm{C}$-glucose in ethanol solution was added to culture media used to label bacteria for feeding experiments and, therefore, bacteria cultured for carbon analysis were grown in similar ethanol concentrations. After a $4 \mathrm{~d}$ incubation period on an orbital shaker at $25^{\circ} \mathrm{C}$, the cells were concentrated at $20^{\circ} \mathrm{C}$ by continuous centrifugation (Sorval RC-2). Finally, the cells were washed with $0.5 \mathrm{M} \mathrm{NaCl}$ by centrifugation and resuspended in $40 \mathrm{ml} 0.5 \mathrm{M} \mathrm{NaCl}$ in a pre-weighed plastic centrifuge tube. All centrifugations, unless otherwise 
specified, were carried out at $20000 \times$ g. A $0.5 \mathrm{ml}$ sample of the bacteria suspension was taken, diluted with $4.5 \mathrm{ml} \mathrm{FSSW}$ and fixed in $2 \%$ ( $\mathrm{w} / \mathrm{v}$, final concentration) buffered formaldehyde $(\mathrm{pH}=8)$. Subsamples of $50 \mu \mathrm{l}$ from the fixed suspension were diluted in $39.95 \mathrm{ml}$ FSSW and bacteria were counted by the acridine orange staining technique of Hobbie et al. (1977). All remaining bacteria were concentrated by centrifugation at $30000 \times \mathrm{g}$, the pellet frozen at $-70^{\circ} \mathrm{C}$ and then freeze-dried. The weight of the centrifuge tube containing the dried bacterial pellet was determined (Sartorius R160P balance), and the weight of the pellet estimated by subtraction of the initial tube weight. Dry weight per CA2 cell was estimated by dividing the dry weight of the bacterial pellet by the number of cells in the pellet. The weight of CA2 cells was determined from 4 separate bacterial cultures. Percent carbon, hydrogen and nitrogen ( $\mathrm{CHN}$ ) content of cells were estimated by analysis of these same 4 bacterial cultures with a Control Equipment Corporation model 240XA CHN analyzer. Carbon content per CA2 cell was calculated by multiplying the dry weight of the cell by its percent carbon content.

Ingestion of bacteria by oyster larvae: direct observation. A technique was developed for feeding oyster larvae on live, stained CA2 cells which permitted direct observation of ingestion of bacteria by $24 \mathrm{~h}$ old larvae. Bacteria (CA2 strain) grown for $4 \mathrm{~d}$ at $25^{\circ} \mathrm{C}$ on marine agar 2216 were transferred to a $50 \mathrm{ml} \mathrm{screw-}$ capped, plastic centrifuge tube containing $35 \mathrm{ml}$ FSSW at a salinity of $30 \mathrm{ppt}$. The cells were suspended in FSSW overnight at $20^{\circ} \mathrm{C}$, then washed by centrifugation for $10 \mathrm{~min}$ and resuspended in $5 \mathrm{ml}$ FSSW. A $0.2 \mu \mathrm{m}$ filtered solution of the stain 4,6-diamidino-2phenylindole (DAPI; Sigma) was added at a final concentration of $10 \mu \mathrm{g} \mathrm{ml}^{-1}$. This concentration did not appear to harm bacteria, considering that no reduction in cell numbers or motility was detected $24 \mathrm{~h}$ following staining. After $10 \mathrm{~min}$ of staining, cells were washed 3 times with FSSW at 20 ppt by repeated centrifugation to remove unbound stain, and were then resuspended in $30 \mathrm{ppt}$ FSSW. Stained cells were filtered at low vacuum pressure $(<2 \mathrm{~cm} \mathrm{Hg}$ ) through $3 \mu \mathrm{m}$ followed by $1 \mu \mathrm{m}$ Nuclepore filters to remove clumped cells. Concentrations of stained bacteria suspensions were determined by measuring absorbance at $600 \mathrm{~nm}$ using a Beckman DU-6 spectrophotometer. Absorption values were converted to equivalent cell concentrations by the equation from Douillet (1991):

$$
\begin{aligned}
\mathrm{CA} 2 \text { cells ml } \mathrm{m}^{-1}= & \left(2.034 \times 10^{9} \times \text { absorbance }\right) \\
& +8.129 \times 10^{5} \quad(\mathrm{r}=0.99)
\end{aligned}
$$

Straight-hinged Crassostrea gigas larvae were obtained from the Whiskey Creek Hatchery, Netarts Bay, Oregon, USA, or by spawning adults at the Hatfield
Marine Science Center, Newport, Oregon. Larvae suspended in FSSW at a density of $15 \mathrm{ml}^{-1}$ were exposed to DAPI-stained CA2 cells at a concentration of $1 \times 10^{7}$ cells $\mathrm{ml}^{-1}$. Samples of larvae were withdrawn every 5 min with a Pasteur pipette, mounted on a depression slide and observed by epifluorescence microscopy using a combination of fluorescent light to detect the stained bacteria and bright light to determine the location of the larvae. A saturated solution of $\mathrm{MgCl}_{2}$ was slowly added to narcotize larvae with their vela extended. Photographs were taken with a MC63 photomicrography system mounted on a Zeiss Universal epifluorescence microscope, using Kodak Ektachrome ASA 200 film.

Ingestion of $\mathrm{CA} 2$ cells by oyster larvae: tracer techniques. A second method to confirm ingestion of CA2 cells by larvae consisted of feeding radioactively labelled bacteria to oyster larvae and measuring accumulation of ${ }^{14} \mathrm{C}$ over time. Bacteria grown on marine agar 2216 for $4 \mathrm{~d}$ were transferred to $1 / 10$ recommended concentration marine broth $2216\left(3.74 \mathrm{~g} \mathrm{l}^{-1}\right)$ at a salinity of $30 \mathrm{ppt}$ and enriched with $0.5 \mathrm{~g}$ glucose $\mathrm{l}^{-1}$. Microbial cultures were incubated at $25^{\circ} \mathrm{C}$ and agitated on an orbital shaker. After $4 \mathrm{~d}$ of growth, the cells were washed twice in FSSW by repeated centrifugation and re-suspension, and then added to $1 / 10$ marine broth 2216. All centrifugations were carried out at $20000 \times g$ for $10 \mathrm{~min}$ and salinity of FSSW was $30 \mathrm{ppt}$. D-(U-14C)glucose (304.7 $\mathrm{mCi} \mathrm{mmol}^{-1}$; NEC-042X, New England Nuclear) in a 9:1 ethanol and water solution was added to the broth at a final concentration of $125 \mu \mathrm{Ci} \mathrm{l}^{-1}$. Bacteria were incubated in the labelling medium for $4 \mathrm{~d}$, harvested and washed twice with FSSW by centrifugation, and transferred to $1 / 10$ marine broth 2216 enriched with $0.5 \mathrm{~g}$ glucose $\mathrm{l}^{-1}$. Following a chase period of $4 \mathrm{~h}$, the cells were washed 3 times by centrifugation. After complete dispersion of cells in FSSW, a $4 \mathrm{ml}$ sample was taken, preserved in $1 \mathrm{ml} 10 \%(\mathrm{w} / \mathrm{v})$ formaldehyde and stored in the dark for up to $5 \mathrm{~d}$ at $5^{\circ} \mathrm{C}$ for determination of cell numbers by the acridine orange staining technique (Hobbie et al. 1977). Four samples of $1 \mathrm{ml}$ each were filtered at low vacuum pressure $(<2 \mathrm{~cm} \mathrm{Hg})$ through $0.45 \mu \mathrm{m}$ Gelman Metricel GN-6 filters, washed with $5 \mathrm{ml} 0.5 \mathrm{M}$ ammonium formate and transferred to scintillation vials, which each received $4 \mathrm{ml}$ Aquasol II (New England Nuclear) and $2 \mathrm{ml}$ distilled water. Samples were gelled by vigorous agitation on a Vortex mixer and radioactivity was measured using a Beckman LS 8000 or LS 6000 TA liquid scintillation counter (LSC). Quench correction was by the external standard ratio method. The specific ${ }^{14} \mathrm{C}$ activity of bacterial cells was determined by dividing the activity of $\mathrm{PO}^{14} \mathrm{C}$ in $1 \mathrm{ml}$ by the number of cells $\mathrm{ml}^{-1}$. Rapid determinations of bacteria concentrations were necessary in larval feeding 
experiments and these determinations were performed spectrophotometrically (see above). Twelve hours before each feeding experiment, larvae were placed at a density of 0.1 to $0.2 \mathrm{ml}^{-1}$ in $200 \mathrm{l}$ tanks containing sand-filtered seawater at $25^{\circ} \mathrm{C}$. Larvae were pre-fed by adding cells of Isochrysis galbana (clone ISO; Center for Culture of Marine Phytoplankton, Maine, USA) at 40000 cells $\mathrm{ml}^{-1}$ to the culture tanks. Algal concentrations did not drop below $50 \%$ of this concentration before the start of experiments. Larvae were washed with FSSW on a $64 \mu \mathrm{m}$ Nitex screen, placed in a separatory funnel and nonswimming larvae were allowed to settle out of suspension before being discarded. A sample of larvae was preserved in $2 \%(\mathrm{w} / \mathrm{v})$ buffered formaldehyde $(\mathrm{pH}=8)$ and copiously rinsed with FSSW on a Nitex screen. Formaldehyde-killed larvae were used as controls for passive uptake of label by larvae, either by direct adsorption of ${ }^{14} \mathrm{C}$ compounds, or by attachment of labelled bacteria to the external surface of the larvae.

${ }^{14} \mathrm{C}$-labelled bacteria were added at final concentrations of $1 \times 10^{5}, 1 \times 10^{6}, 5 \times 10^{6}$ or $1 \times 10^{7} \mathrm{cells} \mathrm{ml}^{-1}$ to $120 \mathrm{ml}$ of FSSW in beakers containing either live larvae at a density of 10 ind $\mathrm{ml}^{-1}$, formalin-killed larvae at a density of 10 ind. $\mathrm{ml}^{-1}$, or FSSW alone. All treatments were duplicated. Water samples for determination of initial concentrations of bacteria and PO ${ }^{14} \mathrm{C}$ were withdrawn after agitation of the larval cultures with plastic plungers. Samples were withdrawn using $10 \mathrm{ml}$ pipettes with $37 \mu \mathrm{m}$ Nitex screens covering their tips, to prevent removal of larvae. Samples were processed as described above and initial ${ }^{14} \mathrm{C}$ activity per bacterial cell calculated.

To determine background ${ }^{14} \mathrm{C}$ activity, 4 subsamples of live larvae and formalin-killed larvae were collected on $8 \mu \mathrm{m}(25 \mathrm{~mm})$ Nuclepore filters, washed with $5 \mathrm{ml}$ $0.5 \mathrm{M}$ ammonium formate, dried by vacuum and transferred while held on the filters to petri dishes where larvae were counted under a dissecting microscope. Moist Whatman GF/C filters (25 mm) were then carefully placed over the larvae held on the Nuclepore filters, to prevent loss of larvae during their transfer from the petri dishes to $20 \mathrm{ml}$ scintillation vials. Protosol (New England Nuclear) tissue solubilizer $(0.5 \mathrm{ml})$ and distilled water $(0.2 \mathrm{ml})$ were added to the scintillation vials and the larvae digested at $50^{\circ} \mathrm{C}$ for 24 h. After complete digestion of larval tissues, $4 \mathrm{ml}$ of Aquasol II and $2 \mathrm{ml}$ distilled water were added, the mixture gelled by vigorous agitation and larval radioactivity determined by LSC. Larval ${ }^{14} \mathrm{C}$ activity was calculated by dividing measured ${ }^{14} \mathrm{C}$ activity by the number of larvae in each sample.

Accumulation of radioactivity in bacteria-fed larvae at each of the 4 tested bacteria concentrations was determined by sampling larvae every $0.5 \mathrm{~h}$ during a $2 \mathrm{~h}$ feeding period. Passive adsorption of radioactivity by formalin-killed larvae $\left(\mathrm{dpm}_{\bar{a} \mathrm{ds}}\right.$ larva $\left.^{-1}\right)$ was assessed at the same sampling intervals. Volumetric pipettes were used to withdraw $20 \mathrm{ml}$ samples of larval suspension from each culture flask.

To estimate the contribution of $\mathrm{DO}^{14} \mathrm{C}$ to larval uptake of radioactivity, larvae were exposed to particlefree filtrates $(0.2 \mu \mathrm{m}$ Nuclepore filtered; $<2 \mathrm{~cm} \mathrm{Hg})$ of the culture medium used in feeding larvae on bacteria for $2 \mathrm{~h}$. Unlabelled larvae were added at a density of 10 ind. $\mathrm{ml}^{-1}$ to the filtrates containing $\mathrm{DO}^{14} \mathrm{C}$ released by labelled bacteria. Control treatments for larval adsorption and absorption of ${ }^{1.4} \mathrm{C}$ were duplicated. Larvae were sampled and processed for accumulated radioactivity $\left(\mathrm{dpm}_{\text {abs. }}\right.$ larva $\left.{ }^{-1}\right)$ after $0.5,1.0,1.5$ and 2.0 h exposure.

Radioactivities accumulated by larvae were calculated by subtracting the mean larval background ${ }^{14} \mathrm{C}$ activity from the ${ }^{14} \mathrm{C}$ activities of larvae determined in each treatment. Radioactivities accumulated by larvae ingesting ${ }^{14} \mathrm{C}$-labelled bacteria $\left(\mathrm{dpm}\right.$ larva $\left.{ }^{-1}\right)$ were estimated by subtracting the sum of both the mean ${ }^{14} \mathrm{C}$ activity accumulated by passive uptake of label (dpm ads. larva ${ }^{-1}$ ) and the mean active uptake of labelled dissolved organic material $\left(\mathrm{dpm}_{\mathrm{abs}}\right.$. larva $\left.{ }^{-1}\right)$ from the mean ${ }^{14} \mathrm{C}$ activity accumulated by live larvae for each sampling time and bacterial concentration.

Assimilation of bacteria by oyster larvae. Retention of bacterial carbon was used as an estimate of assimilation of bacteria by oyster larvae (Johannes \& Satomi 1967, Pechenik \& Fisher 1979). The experimental design for evaluating carbon retention requires a preliminary determination of the time needed to purge the larval guts of unassimilated bacterial carbon.

Depuration of larval digestive system. Live algae have been used to purge the digestive system of mollusc larvae of non-absorbed ${ }^{14} \mathrm{C}$ material (Pechenik \& Fisher 1979). However, live algal foods could take up $\mathrm{DO}^{14} \mathrm{C}$ released by larvae, and thus affect estimation of larval ingestion and retention of bacterial ${ }^{14} \mathrm{C}$. Therefore, dead ${ }^{60} \mathrm{Co}$-irradiated cells, which were ingested at high rates by oyster larvae (Douillet 1991), were used to purge the digestive systems of larvae. ${ }^{60} \mathrm{Co}-$ irradiated cells were prepared by initially centrifuging cells from axenic cultures of Isochrysis galbana. The algal paste was stored in a $20 \mathrm{ml}$ scintillation vial under a nitrogen atmosphere. The paste was sterilized by ${ }^{60} \mathrm{Co}$ irradiation (5 megarads) at the Radiation Center of Oregon State University and stored in the dark at $5^{\circ} \mathrm{C}$. Irradiated cells did not grow when incubated under conditions that permitted growth of living cells. Sterility of the irradiated paste was confirmed by aerobic or anaerobic (BBL GasPak Pouch) incubations in $1 / 10$ diluted marine broth $2216\left(3.74 \mathrm{~g} \mathrm{l}^{-1}\right)$ at $25^{\circ} \mathrm{C}$. 
Larvae were placed in 4 beakers filled with FSSW at a density of 10 ind. $\mathrm{ml}^{-1} \cdot{ }^{14} \mathrm{C}$-labelled CA2 cells were added to the beakers at $1 \times 10^{7}$ cells $\mathrm{ml}^{-1}$, a bacteria concentration that resulted in highest bacterial ingestion rates for larvae in the preceding experiment. After a period of $2 \mathrm{~h}$, in which larvae were fed on ${ }^{14} \mathrm{C}$-labelled cells, larvae were washed with FSSW on a $64 \mu \mathrm{m}$ Nitex screen and transferred to beakers containing $380 \mathrm{ml}$ of a suspension of 30 cells $\mu \mathrm{l}^{-1}$ of ${ }^{60} \mathrm{Co}$-irradiated Isochrysis galbana. A $20 \mathrm{ml}$ sample (ca 200 larvae) was immediately taken from each flask for determination of larval ${ }^{14} \mathrm{C}$ activity, followed by additional $20 \mathrm{ml}$ samples taken every 10 min during the first $2 \mathrm{~h}$ of the purge period, and thereafter at 3,4 , $6.3,24$ and $48 \mathrm{~h}$ in order to determine rates of gut evacuation.

Control treatments for both passive and active ${ }^{14} \mathrm{C}$ uptake were set up as described in the previous experiment. Four replicates were set up for each treatment. After $2 \mathrm{~h}$ exposure to either labelled bacteria or to the labelled dissolved fraction, both live and formalinkilled control larvae were washed and transferred to suspensions of irradiated algae to determine the loss of accumulated label over time.

Labelled carbon remaining in larvae during or after depuration (dpm larva ${ }^{-1}$ ) was determined by subtracting the sum of the mean activities of larvae in controls for passive uptake of label (dpmads. larva ${ }^{-1}$ ) and for active uptake of dissolved label (dpmabs. larva $\left.^{-1}\right)$, from the ${ }^{14} \mathrm{C}$ activity remaining in bacteria-fed larvae at each sampling time. In this way, the rate of gut evacuation was determined.

Carbon retention by larvae fed on live or dead bacteria. An experiment was designed to test the hypothesis that ingested CA 2 carbon was digested and retained by oyster larvae. Retention efficiencies and amounts of carbon retained by axenic larvae fed on either live or heat-killed bacteria were determined and compared. The ability of axenic larvae to retain ${ }^{14} \mathrm{C}$ from ingested ${ }^{14} \mathrm{C}$-labelled CA2 cells after completely purging them of ${ }^{14} \mathrm{C}$ material suggests that larvae do not need a gut flora to digest CA2 cells. Furthermore, retention of ${ }^{14} \mathrm{C}$ by axenic larvae, fed on heat-killed CA2 cells, would indicate that ${ }^{14} \mathrm{C}$ activity accumulated and retained by larvae fed on living CA2 cells was not attributable to label recycling by CA.2 cells or to bacterial colonization of the digestive systems of larvae, but due to larval ingestion, digestion and absorption of ${ }^{14} \mathrm{C}$ from ${ }^{14} \mathrm{C}$-labelled CA2 cells.

All glassware was acid washed, rinsed 7 times with distilled water and baked overnight at $450^{\circ} \mathrm{C}$. Filtered $(0.2 \mu \mathrm{m})$ seawater was added to beakers that were capped with aluminum foil and sterilized by autoclaving. Screened chambers (described below) were sterilized separately in autoclavable bags, and then aseptically placed in the sterile beakers. Manipulations were performed under a laminar-flow hood.

CA2 cells were labelled with ${ }^{14} \mathrm{C}$-glucose as described above. Half the CA2 culture was washed by centrifugation, resuspended in $35 \mathrm{ml}$ of FSSW and heated at $95^{\circ} \mathrm{C}$ for $6 \mathrm{~h}$. This treatment killed the cells (no growth in either solid or liquid marine 2216 culture media) without destroying their structural integrity. The other half of the culture of ${ }^{14} \mathrm{C}$-labelled bacteria was washed by centrifugation and then transferred to $1 / 10$ diluted marine broth $2216\left(3.74 \mathrm{~g} \mathrm{l}^{-1}\right)$ enriched with $0.5 \mathrm{~g} \mathrm{l}^{-1}$ unlabelled glucose and cultured for a $6 \mathrm{~h}$ chase period. Both living and heat-killed bacteria were then washed 3 times by centrifugation and resuspended in $35 \mathrm{ml}$ FSSW. Bacteria concentrations were estimated by optical density.

Bacteria-free oyster larvae were obtained according to the method described by Langdon (1983). When the trochophore larvae had developed into veligers (straight-hinged larvae), subsamples of larvae were aseptically withdrawn for axenicity tests, and the remaining larvae were then held at $5^{\circ} \mathrm{C}$ for $5 \mathrm{~d}$. Axenicity of larvae was determined by epifluorescence microscopy using DAPI-staining techniques (Porter \& Feig 1980). Samples of larvae were also added to $1 / 10$ recommended concentration of marine broth 2216 $\left(3.74 \mathrm{~g} \mathrm{l}^{-1}\right.$, salinity $\left.30 \mathrm{ppt}\right)$ and incubated at $25^{\circ} \mathrm{C}$ under aerobic or anaerobic conditions (BBL GasPak Pouch). Larvae from cultures that showed no evidence of microbial contamination from either the epifluorescence test or the $5 \mathrm{~d}$ broth incubations were considered adequate for experimentation. To confirm that the larvae were axenic, broth incubations were continued for 30 d. Axenic larvae were washed with FSSW on a sterile $64 \mu \mathrm{m}$ Nitex screen and transferred at a density of 25 $\mathrm{ml}^{-1}$ to 4 sterile screened chambers held in $1 \mathrm{l}$ beakers filled with $400 \mathrm{ml}$ FSSW. Each screened chamber consisted of a PVC tube $(3.85 \mathrm{~cm}$ radius) with a $64 \mu \mathrm{m}$ Nitex screen covering its base. Either live or heatkilled bacteria were added to larval suspensions at a concentration of $10^{7}$ cells $\mathrm{ml}^{-1}$, a bacteria concentration that resulted in highest bacterial ingestion rates for larvae in the preceding experiment. Initial bacterial ${ }^{14} \mathrm{C}$ activities were determined as described in preceding experiments. Control treatments for passive label adsorption and active $\mathrm{DO}{ }^{14} \mathrm{C}$ uptake were set up as described above. All treatments were duplicated. After $2 \mathrm{~h}$ exposure to either labelled bacteria or to the labelled dissolved fraction, both live and formalinkilled control larvae were washed and transferred to suspensions of irradiated algae to determine the loss of accumulated label over time.

After allowing larvae to feed on ${ }^{14} \mathrm{C}$-labelled cells for $10 \mathrm{~min}$, the screened chambers containing the larvae 
were removed from the bacteria suspensions, washed with FSSW and transferred to beakers to allow larvae to purge themselves on a diet of axenic ${ }^{60} \mathrm{Co}$-irradiated algae $\left(30\right.$ cells $\left.\mu l^{-1}\right)$. Immediately after resuspension of the larvae, two $20 \mathrm{ml}$ samples per chamber were taken for determination of accumulated radioactivity in larvae. Subsequently, screened chambers containing larvae were removed from suspensions of irradiated algae every $3 \mathrm{~h}$, washed with FSSW and transferred to fresh, axenic, irradiated algae suspensions. Frequent water changes reduced the risk of reingestion of ${ }^{14} \mathrm{C}$-labelled fecal material by larvae. Duplicate samples of larvae were taken from each chamber after transfer to fresh, irradiated algae suspensions. The volume of the irradiated algae suspension was reduced at each transfer in order to maintain constant larval densities over the purge period. After a purge period of $9 \mathrm{~h}$, larvae were next transferred to fresh, irradiated algae suspensions for $24 \mathrm{~h}$. At the end of the experiment, larvae previously fed heat-killed bacteria were sampled and tested for microbial contamination as previously described.

Average ${ }^{14} \mathrm{C}$ activities per larva were calculated from duplicate samples taken from each replicated beaker at each sampling time. Rates of gut emptying under both treatment conditions (live or heat-killed bacteria) were determined as described in the preceding experiment. Radioactivity determined in larvae after $10 \mathrm{~min}$ feeding on ${ }^{14} \mathrm{C}$-labelled bacteria [dpm ingested larva ${ }^{-1}$ $\left(10 \mathrm{~min}^{-1}\right.$ ] permitted estimation of ingestion rates because the feeding period was shorter than the larval gut passage time. Ingestion rates (IR) for larvae fed on CA2 cells over a 10 min feeding period were calculated as follows:

$\mathrm{IR}=\mathrm{dpm}$ ingested larva ${ }^{-1}(10 \mathrm{~min})^{-1} / \mathrm{dpm} \mathrm{cell}^{-1}$

Clearance rates $\left(\mu l\right.$ larva $\left.{ }^{-1} \mathrm{~h}^{-1}\right)$, defined here as the volume of water swept clear of particles in unit time, were estimated by dividing ingestion rates (extrapolated to hourly rates as cells larva ${ }^{-1} \mathrm{~h}^{-1}$ ) by the initial concentration of bacteria in the larvae suspension (cells $\mu^{-1}$ )

Retention efficiency of bacterial ${ }^{14} \mathrm{C}$ (RE) was calculated as:

$\mathrm{RE}=\left[\mathrm{dpm}\right.$ retained larva ${ }^{-1} / \mathrm{dpm}$ ingested larva $\left.{ }^{-1}\right] \times 100$

Larval retention efficiencies determined for each bacterial cell type were arcsine-transformed and compared using a 2-sample t-test (Sokal \& Rohlf 1981).

Assuming that CA2 cells were homogeneously labelled after culture for several days in ${ }^{14} \mathrm{C}$-labelled media, then the amount of carbon retained by each larva (C.RET,) after 10 min feeding on labelled food, followed by a complete purge of the digestive system with non-labelled food, was estimated as:

$$
\text { C.RET. }=I R \times \text { cell carbon content } \times \text { RE } / 100
$$

where IR was expressed in terms of cells larva ${ }^{-1}$ $(10 \mathrm{~min})^{-1}$ and the carbon content of CA2 was expressed as pg $\mathrm{C} \mathrm{cell}^{-1}$.

\section{RESULTS AND DISCUSSION}

\section{Size and biovolume of CA2 cells}

The average length of CA2 cells was $0.87 \mu \mathrm{m}$ (SD = $0.16 \mu \mathrm{m}, \mathrm{n}=100$ ), while the average width was $0.41 \mu \mathrm{m}$ $(\mathrm{SD}=0.047 \mu \mathrm{m}, \mathrm{n}=100)$. The size of Strain CA2 was within the size range reported for bacteria in estuarine and coastal waters (Wright et al. 1982, Palumbo et al 1984). The average biovolume of CA2 cells was estimated to be $0.0968 \mu^{3}$, which is within the range for naturally occurring bacterioplankton $\left(0.02\right.$ to $\left.0.17 \mu \mathrm{m}^{3}\right)$ determined by Fergusson \& Rublee (1976), Fuhrman (1981), Palumbo et al. (1984) and Riemann et al. (1984). Therefore, ingestion rates for larvae fed on CA2 bacteria reported in this study could represent ingestion rates for larvae feeding on natural bacterioplankton, if larvae do not discriminate among different bacterial strains based on other factors apart from size.

\section{Carbon content of Strain CA2}

The average weight of freeze-dried CA2 cells was $6.17 \times 10^{-14} \mathrm{~g} \mathrm{cell}^{-1} \pm 0.53 \times 10^{-14}(\bar{x} \pm \mathrm{SD}, \mathrm{n}=4)$. Average values for percent carbon, hydrogen and nitrogen for CA2 cells were $41.88 \pm 1.94 \%, 6.45 \pm 0.65 \%, 12.15 \pm$ $1.42 \%$. The atomic carbon to nitrogen ratio was 4.01 . Studies which address bacterial carbon content on a carbon per dry weight basis report ratios from 0.344 (Ferguson \& Rublee 1976) to 0.5 (Luria 1960). The carbon to dry weight ratio determined for CA2 cells was 0.42 . The average carbon content per CA2 cell was estimated to be $25.8 \pm 2.6 \mathrm{fg} \mathrm{cell}^{-1}(\mathrm{n}=4)$. Lee \& Fuhrman (1987) found that marine bacterioplankton had a carbon content of $20 \mathrm{fg} \mathrm{cell}^{-1}$, while Bratbak (1985) determined the amount of carbon in Pseudomonas putida to be between 129 and $312 \mathrm{fg} \mathrm{cell}^{-1}$. Variation in the size of marine bacteria combined with the finding that small bacteria tend to have higher carbon to volume ratios (Lee \& Fuhrman 1987) could explain the range of values reported for the carbon content per cell for marine bacteria. So, bacterial carbon to biovolume ratio $\left(\mathrm{g} \mathrm{C} \mathrm{cm}^{-3}\right)$ is a more useful estimate for comparisons. Reported carbon to biovolume ratios for bacteria in $\mathrm{g} \mathrm{C} \mathrm{cm}^{-3}$ vary from 0.106 (Nagata 1986) to 0.56 (Bratbak 1985). Therefore, the carbon to biovolume ratio estimated for Strain CA2 $\left(0.266 \mathrm{~g} \mathrm{C} \mathrm{cm}^{3}\right)$ is within the reported range for marine bacteria. 


\section{Ingestion of CA2 cells by oyster larvae: direct observation}

Microscopic observations of straight-hinged larvae fed DAPI-stained CA2 cells revealed that after only 5 min of grazing, large accumulations of stained bacteria were present in the digestive systems of larvae (Fig. 1). Stained bacteria were concentrated in the stomach, digestive gland and upper intestine of some larvae. A few single bacterial cells were released with feces after only $15 \mathrm{~min}$ of grazing, but most bacteria were retained in the digestive systems of larvae during this period of initial feeding. DAPI fluorescence of bacteria in the guts of larvae faded within several hours following exposure to stained cells, while noningested stained cells were fluorescent for over $24 \mathrm{~h}$. Patterns of stain accumulation and gut passage times were consistent among repeated observations. Control larvae exposed to dilute concentrations of DAPI absorbed the stain through the velum, resulting in a different distribution of stain in the larvae from that occurring in larvae fed on stained bacteria, where fluorescence only appeared in the digestive system.

\section{Ingestion of CA2 cells by oyster larvae: tracer techniques}

Larvae accumulated radioactivity when exposed to bacteria concentrations between $1 \times 10^{5}$ and $1 \times 10^{7}$ cells $\mathrm{ml}^{-1}$. This radioactivity level in larvae corresponded to the net accumulated activity because of ${ }^{14} \mathrm{C}$ losses due to larval respiration and excretion. Uptake of label by active absorption of $\mathrm{DO}^{14} \mathrm{C}\left(\mathrm{dpm}_{\mathrm{abs}}\right.$. larva $\left.{ }^{-1}\right)$ accounted for 10 to $19 \%$ of net accumulated larval activity. Passive adsorption of label by formalin-killed larvae $\left(\mathrm{dpm}_{\mathrm{ads}}\right.$. larva $\left.{ }^{-1}\right)$ was equal to 7.1 to $11.9 \%$ of

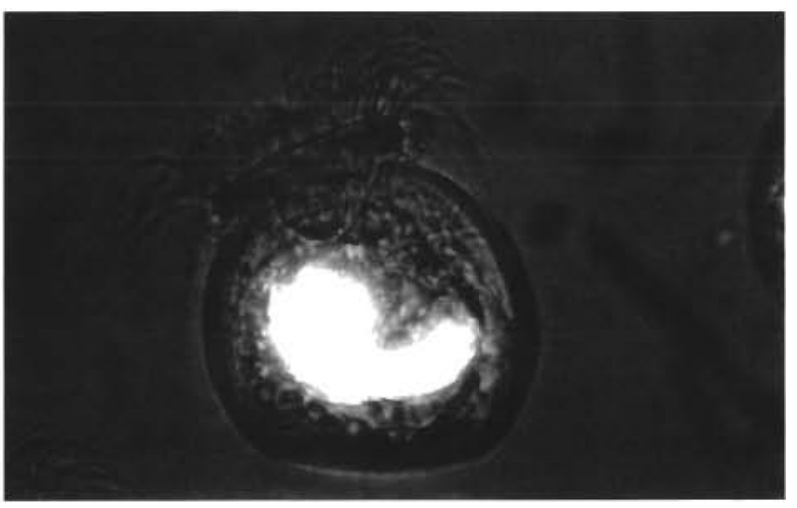

Fig. 1. Crassostrea gigas. Photograph of straight-hinged oyster larva (shell length $100 \mu \mathrm{m}$ ) after 5 min of grazing on DAPIstained CA2 cells. Fluorescence of larval digestive systems is the result of ingestion of stained CA2 cells

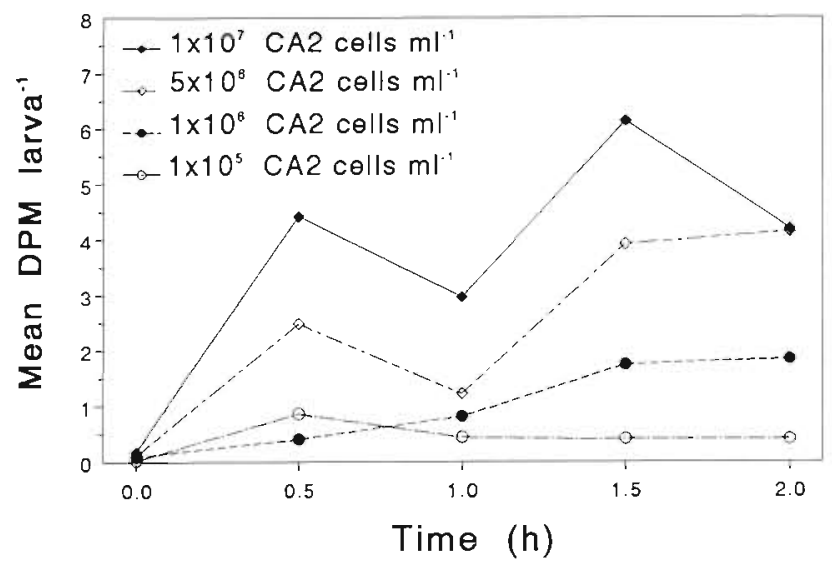

Fig. 2. Crassostrea gigas. Patterns of ingestion of $\mathrm{PO}^{14} \mathrm{C}$ in straight-hinged oyster larvae fed ${ }^{14} \mathrm{C}$-labelled CA2 bacteria at different cell concentrations. Symbols represent the means of 2 replicates. For clarity, the range of values obtained was omitted

net accumulated activity. Larval radioactivity after subtraction of dpmabs. larva $^{-1}$ and dpmads. larva $^{-1}$ represented net activity accumulated through ingestion of $\mathrm{PO}^{14} \mathrm{C}$ (Fig. 2). The cyclical pattern of accumulation rates of radioactivity by larvae fed at the 2 highest bacterial concentrations $\left(5 \times 10^{6}\right.$ and $1 \times 10^{7}$ cells $\left.\mathrm{ml}^{-1}\right)$ is similar to the pattern observed by Gallager et al. (1989) with scallop Argopecten irradians larvae fed ${ }^{14} \mathrm{C}$-labelled algae. The latter authors suggested that this pattern was caused by cycles of gut filling and emptying of the digestive systems of larvae.

Concentrations of bacteria in the marine environment usually range between $10^{5}$ and $10^{6}$ cells $\mathrm{ml}^{-1}$ (Sieburth et al. 1978, Fuhrman 1981, ChretiennotDinet 1982, Moriarty et al. 1985, Andersen \& Sorensen 1986). However, higher concentrations of bacteria have been reported in eutrophic coastal waters (1.5 $\times 10^{7}$ cells $\mathrm{ml}^{-1}$; Andersen \& Sorensen 1986), coastal waters following algal blooms $\left(1.2 \times 10^{7}\right.$; Tracey et al. 1988), estuaries (1.5 to $1.8 \times 10^{7}$ cells ml-1; Palumbo \& Ferguson 1978, Wright et al. 1982), salt marshes $\left(1.9 \times 10^{7}\right.$ cells $\mathrm{ml}^{-1}$; Wilson \& Stevenson 1980$)$, oyster ponds $\left(2 \times 10^{7}\right.$ cells $^{-1}$; Frikha \& Linley 1988/ $1989)$ and in larval culture tanks in hatcheries $(3.8 \times$ $10^{6}$ cells $\mathrm{ml}^{-1}$; Jeanthon et al. 1988). So, straighthinged oyster larvae must be able to ingest large quantities of bacteria from natural environments as well as from intensive production systems.

\section{Assimilation of bacteria by oyster larvae}

Difficulties associated with measuring assimilation of food by zooplankton have been discussed by Johannes \& Satomi (1967), Conover \& Francis (1973) and Lampert 
(1977). Several methods proposed for determination of assimilation efficiencies cannot be used with bivalve larvae because of methodological considerations or violations of the assumptions on which these methods are based. One of these methods consists of measuring the radioactivity of animals at 2 different times after the gut is filled with radioactive food (Rigler 1971) Possible problems in larval-feeding studies with this technique include label recycling while the larvae are filling their guts with radioactive food and nonlinearity in the accumulation of radioactivity by larvae. The ${ }^{14} \mathrm{C}-{ }^{51} \mathrm{Cr}$ dual tracer method (Calow \& Fletcher 1972) has been used with bivalve larvae (Nelson \& Siddall 1988); however, sources of error discussed by these authors included different gut passage times for the 2 isotopes, dissolution of feces and the confounding effects of bacterial and algal respiration. Another ${ }^{14} \mathrm{C}$ method for determination of carbon assimilation has been described by Sorokin (1966) and consists of feeding animals for a definite period of time with radioactive food, followed by transfer of animals to nonradioactive food to purge their guts of radioactive material, and finally measurement of the remaining radioactivity incorporated into the animals' tissues. Losses of ${ }^{14} \mathrm{C}$ through respiration and excretion should be added to the radioactivity incorporated by the grazers in order to determine assimilated ${ }^{14} \mathrm{C}$. Respiration of ${ }^{14} \mathrm{C}$ by the grazers should be determined during the feeding period on radioactive food (Lampert 1977). and during the purge period with non-radioactive food. One difficulty in obtaining accurate estimates of assimilated matter is determination of the distribution of ${ }^{14} \mathrm{C}$ among fractions of labelled dissolved organic matter corresponding to larval excretion, leakage of ingested carbon (Pechenik 1979), disintegration of feces and release of label by bacteria. A second difficulty involves separation of ${ }^{14} \mathrm{C}$ respiration of labelled bacteria from that of larvae during the larval grazing period and during the purge period. Estimation of retention efficiencies, defined as the percentage of ingested carbon that is retained by an animal after it has emptied its gut (Johannes \& Satomi 1967, Pechenik $\&$ Fisher 1979), can be used to avoid these potential sources of error. Carbon retention is equal to carbon assimilation minus metabolic losses of carbon occurring during the experiment. Therefore, carbon retention is a conservative estimate of carbon assimilation.

\section{Depuration of larval digestive system}

In order to determine retention of bacterial carbon, the time scale for complete purge of non-absorbed ${ }^{14} \mathrm{C}$ material in larval guts must be determined. Active absorption $\left(\mathrm{dpm}_{\mathrm{abs}} \operatorname{larva}^{-1}\right)$ and passive adsorption (dpmads. larva $\left.{ }^{-1}\right)$ were found to represent respectively 9.5 to $17.8 \%$ and 4.7 to $10.8 \%$ of the net ${ }^{14} \mathrm{C}$ activity accumulated by larvae after a $2 \mathrm{~h}$ grazing period. After subtraction of dpm $_{a b s}$. larva ${ }^{-1}$ and dpmads. larva $^{-1}$ from the net ${ }^{14} \mathrm{C}$ activity of larvae at each sampling time, the rate of gut evacuation was characterized by a rapid decline in ${ }^{14} \mathrm{C}$ activity during the first $10 \mathrm{~min}$, followed by a more gradual decrease in activity during the next $4 h$, and finally by a linear decrease till the 48 th h of the purge period (Fig. 3). At 48 h, larvae retained from 28.9 to $39.3 \%$ of the activity accumulated after $2 \mathrm{~h}$ exposure to ${ }^{14} \mathrm{C}$-labelled CA2 cells. Particles ingested by molluscan larvae are sorted in the stomach whereas non-digested particles are moved directly to the intestine, and particles to be digested are taken into the digestive diverticula for intracellular digestion (Bayne 1983). The rapid decline in activity during the first $10 \mathrm{~min}$ of purge was primarily due to the release of unassimilated ${ }^{14} \mathrm{C}$ material from the intestine, whilst the slower decline in activity during the next $3 \mathrm{~h}$ was probably due to the purge of the digestive diverticula and to respiratory and excretory losses of label. The linear loss of activity in larvae from the 4 th to the 48 th $\mathrm{h}$ of purge was likely caused exclusively by respiratory and excretory losses of assimilated ${ }^{14} \mathrm{C}$. Complete depuration of the larval digestive system including the digestive diverticula is essential for determination of carbon retention. Therefore, the most conservative approach was to select a long depuration time $(>4 \mathrm{~h}$ ) resulting in underestimation of carbon assimilated because of ${ }^{14} \mathrm{CO}_{2}$ respiration and ${ }^{14} \mathrm{C}$ excretion. The pattern of gut depuration of oyster larvae after feeding on ${ }^{14} \mathrm{C}$ labelled bacteria in this study was similar to patterns observed with mud snail Nassarius obsoletus larvae

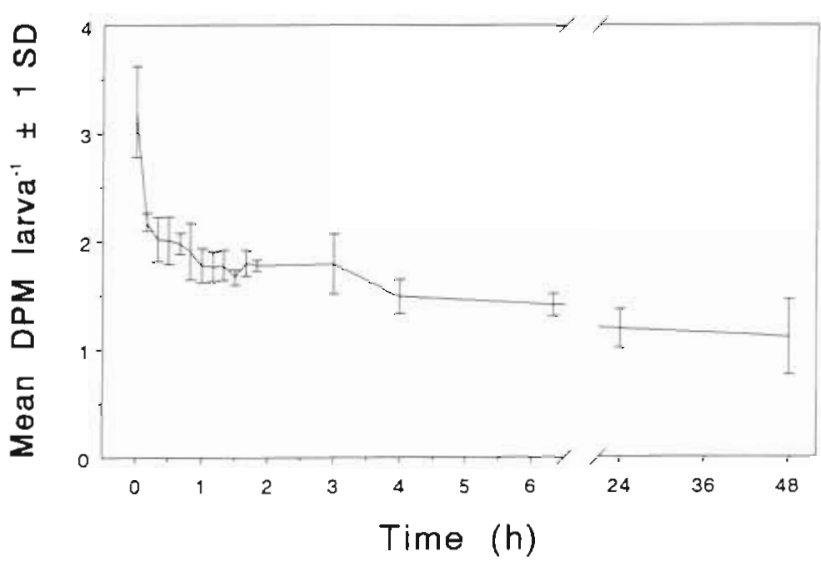

Fig. 3. Crassostrea gigas. Rate of gut evacuation of straighthinged oyster larvae fed for $2 \mathrm{~h}$ on ${ }^{14} \mathrm{C}$-labelled CA2 bacteria at $1 \times 1.0^{7}$ cells $\mathrm{ml}^{-1}$ and then depurated in filtered seawater containing 30 cells $\mu \mathrm{I}^{-1}$ of ${ }^{60} \mathrm{Co}$-irradiated Isochrysis galbana.

Symbols represent means and standard deviations $(\mathrm{n}=4)$ 
(Pechenik \& Fisher 1979) and scallop Argopectens irradians larvae (Gallager et al. 1989) when both were fed on ${ }^{14} \mathrm{C}$-labelled algae.

\section{Carbon retention efficiencies and amounts of carbon retained by larvae fed on live or dead CA2 cells}

${ }^{14} \mathrm{C}$ activities of live and heat-killed CA2 cells immediately after addition of cells to larvae suspensions were determined to be $1.503 \times 10^{-4} \pm 2.97 \times 10^{-6}(\bar{x} \pm$ $\mathrm{SD}, \mathrm{n}=4$ ) and $1.077 \times 10^{-4} \pm 3.32 \times 10^{-6} \mathrm{dpm} \mathrm{cell}^{-1}$ respectively. Active uptake of dissolved ${ }^{14} \mathrm{C}$ by larvae exposed to leachates of live or heat-killed CA2 cells accounted respectively for 7.2 to 9 and 11.5 to $15.3 \%$ of net accumulated ${ }^{14} \mathrm{C}$ activity in larvae fed on these cell types. Uptake of dissolved ${ }^{14} \mathrm{C}$ and ${ }^{3} \mathrm{H}$ compounds was reported respectively as 31 and $26 \%$ of total radioactive uptake by Crassostrea virginica larvae exposed for $10 \mathrm{~min}$ to 0.2 to $0.8 \mu \mathrm{m}$ sized, ${ }^{14} \mathrm{C}$ - and ${ }^{3} \mathrm{H}$-labelled naturally-occurring particles (Baldwin \& Newell 1991). Passive adsorption of ${ }^{14} \mathrm{C}\left(\mathrm{dpm}_{\text {ads }}\right.$ larva ${ }^{-1}$ ) was determined to be 5.9 to 6.7 and 5 to $6.7 \%$ of net ${ }^{14} \mathrm{C}$ activities accumulated in larvae fed live or heat-killed CA2 cells respectively. Larvae used as controls for passive adsorption and active absorption of ${ }^{14} \mathrm{C}$ were exposed to ${ }^{14} \mathrm{C}$ suspensions for $2 \mathrm{~h}$. In contrast, larvae in feeding treatments were exposed to ${ }^{14} \mathrm{C}$-labelled bacteria for only $10 \mathrm{~min}$. Therefore, subtracting the ${ }^{14} \mathrm{C}$ activity in the controls from the ${ }^{14} \mathrm{C}$ activity in the feeding treatments resulted in conservative estimates of labelled carbon remaining in larvae during feeding and depuration. Larvae retained carbon from both heat-killed and live CA2 cells after a $24 \mathrm{~h}$ purge period (Fig. 4). Larvae fed on heat-killed bacteria were still axenic at the end of the $24 \mathrm{~h}$ purge period.

Cell concentrations and the number of cells ingested by larvae differed between treatments (Table 1 ; $t$-test, $p=0.01$ and $p=0.03$ respectively). Microscopic examination revealed that even after filtration through a $1 \mu \mathrm{m}$ Nuclepore filter, heat-killed CA2 cells tended to clump together when suspended in seawater. Clumping of bacteria cells probably increased the efficiency with which cells were captured by larvae and, therefore, resulted in the significantly higher ingestion rates for larvae fed heat-killed bacteria. Clearance rates, retention efficiencies and the amount of carbon retained by larvae fed on heat-killed cells appeared higher than for larvae fed on live CA2 cells (Table 1), however, the differences were not found to be statistically significant $(t$-test $; \mathrm{p}=0.09, \mathrm{p}=$

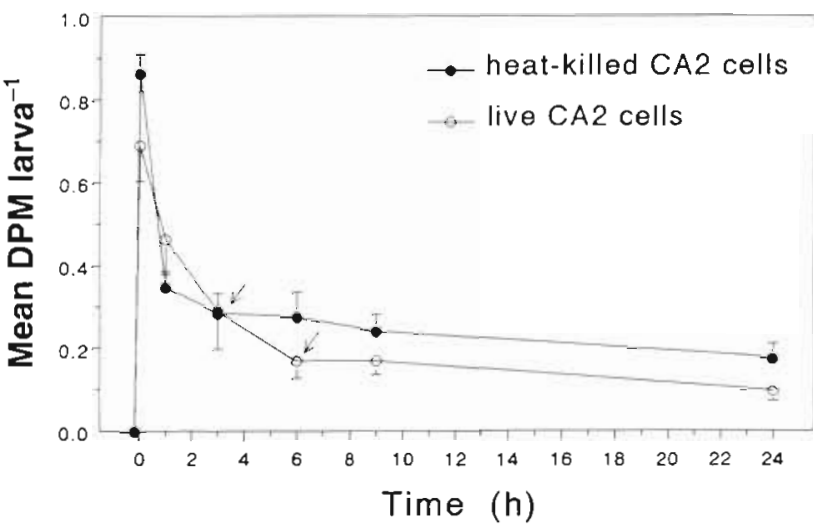

Fig. 4. Crassostrea gigas. Rate of ingestion and gut evacuation of bacteria-free, straight-hinged oyster larvae fed for $10 \mathrm{~min}$ on either live or heat-killed ${ }^{14} \mathrm{C}$-labelled $\mathrm{CA} 2$ bacteria and then depurated in filtered seawater containing $30 \mathrm{cells} \mu \mathrm{I}^{-1}$ of ${ }^{60} \mathrm{Co}$-irradiated Isochrysis galbana. Symbols represent the means of 2 replicates and are shown with the range of values obtained. Arrows indicate points after which larvae were considered purged of ingested ${ }^{14} \mathrm{C}$

0.12 and $p=0.06$ respectively). Possible changes in the structure of bacteria cell walls caused by heat treatment may have facilitated digestion; however, carbon retention efficiencies and the amounts of carbon retained by larvae after feeding on live or heat-killed bacteria were not different, demonstrating the endogenous ability of larvae to assimilate bacterial carbon.

Xenic straight-hinged oyster larvae exposed to CA2 bacteria at similar concentrations than in this last experiment had comparable clearance and ingestion rates (Douillet 1991). However, carbon retention effi-

Table 1. Summary of results of ${ }^{14} \mathrm{C}$ retention experiment conducted with bacteria-free, straight-hinged oyster larvae fed for $10 \mathrm{~min}$ on either live or heat-killed ${ }^{14} \mathrm{C}$-labelled CA2 cells and then purged for $24 \mathrm{~h}$ in seawater containing 30 cells $\mu \mathrm{l}^{-1}$ of ${ }^{60} \mathrm{Co}$-irradiated Isochrysis galbana. Values of 2 replicates per treatment are presented

\begin{tabular}{|c|c|c|c|}
\hline \multirow[t]{2}{*}{ Parameter } & \multicolumn{2}{|c|}{ CA2 cell type } & \multirow{2}{*}{$\begin{array}{l}\text { 2-sample } t \text {-test } \\
\text { p }\end{array}$} \\
\hline & Live & Heat-killed & \\
\hline $\begin{array}{l}\text { CA2 concentration } \\
\text { (cells } \mathrm{ml}^{-1} \text { ) }\end{array}$ & $\begin{array}{l}2.077 \times 10^{-7} \\
2.303 \times 10^{-7}\end{array}$ & $\begin{array}{l}3.164 \times 10^{-7} \\
3.396 \times 10^{-7}\end{array}$ & 0.010 \\
\hline $\begin{array}{l}\text { Clearance rate } \\
\left.(\mu] \text { larva }^{-1} \mathrm{~h}^{-1}\right)\end{array}$ & $\begin{array}{l}1.186 \\
1.316\end{array}$ & $\begin{array}{l}1.396 \\
1.542\end{array}$ & 0.087 \\
\hline $\begin{array}{l}\text { Ingestion rate } \\
\text { (cells larva }{ }^{-1} 10 \mathrm{~min}^{-1} \text { ) }\end{array}$ & $\begin{array}{l}4099 \\
5047\end{array}$ & $\begin{array}{l}7355 \\
8719\end{array}$ & 0.027 \\
\hline $\begin{array}{l}\text { Percent carbon } \\
\text { retention efficiency }\end{array}$ & $\begin{array}{l}21.46 \\
26.94\end{array}$ & $\begin{array}{l}29.26 \\
36.52\end{array}$ & 0.117 \\
\hline $\begin{array}{l}\text { CA2 carbon retained } \\
\left(\mathrm{pg} \mathrm{C} \text { larva }^{-1} 10 \mathrm{~min}^{-1} \text { ) }\right.\end{array}$ & $\begin{array}{l}22.72 \\
35.18\end{array}$ & $\begin{array}{l}55.21 \\
81.81\end{array}$ & 0.062 \\
\hline
\end{tabular}


ciencies and the amounts of carbon retained were lower in the experiment using bacteria-free larvae. The method used to obtain axenic larvae (storage of starved larvae in the same culture medium for $5 \mathrm{~d}$ at $5^{\circ} \mathrm{C}$ ) may have stressed larvae and affected their assimilation efficiency. Also, production of digestive enzymes might have been induced in xenic larvae by their previous feeding, either on particles remaining in sand-filtered seawater, or on algae, available at optimal concentrations for bivalve larvae during the $12 \mathrm{~h}$ before the experimental trials (Douillet 1991). Finally, symbiotic gut flora may have enhanced the assimilation efficiency in xenic larvae.

Several potential problems in feeding experiments with suspension-feeding marine bivalves and bacteria were considered. (1) Accurate quantification of ingestion of labelled cells is required to estimate retention efficiency. Observations of larvae fed on DAPI-stained CA2 cells revealed that some bacteria would pass unharmed through the guts of larvae after $15 \mathrm{~min}$ exposure of larvae to the microbial suspension. Estimates of a gut passage time of $10 \mathrm{~min}$ have been reported for larvae of the oyster Crassostrea virginica (Baldwin \& Newell 1991) and $30 \mathrm{~min}$ for scallop larvae fed fluorescent paint particles (Nelson \& Siddall 1988). A short term (10 $\mathrm{min}$ ) pulse-feed with ${ }^{14} \mathrm{C}$-labelled bacteria allowed estimation of ingestion rates, reduced both the probability of label recycling among bacteria, larvae and seawater, and the probability of larval ingestion of defecated bacteria. (2) Larval re-ingestion of feces during the purge period may affect carbon retention determinations, so water changes during the purge period were as frequent as practical. (3) The use of ${ }^{60} \mathrm{Co}$-irradiated algae for purging larvae eliminated the possibility of label recycling through active uptake of dissolved ${ }^{14} \mathrm{C}$ label by algae. (4) In order to guarantee complete depuration of larval digestive systems, including the digestive diverticula, long depuration times were selected resulting in underestimation of carbon assimilation as described above. (5) Certain bacteria strains do not appear to be digested and may even multiply while passing through the guts of bivalve larvae (Prieur 1981). Therefore, ingested bacteria may resist digestion and colonize the guts of larvae so that ${ }^{14} \mathrm{C}$ activity present after the purge period would not be due to absorbed carbon but due to the presence of a gut microflora of ${ }^{14} \mathrm{C}$-labelled bacteria. The use of heat-killed bacteria controlled for this latter possibility. (6) The presence of bacteriolytic activity associated with bacteria isolated from the crystalline styles of Mytilus edulis (Seiderer et al. 1987) suggests that gut bacteria may affect the results of assimilation studies in which bacteria are fed to bivalve larvae by enhancing the digestion of ingested bacterial cells. The use of axenic larvae without a gut microflora allowed determination of the endogenous ability of the larvae to use ingested bacteria as a food source. The results presented in this manuscript demonstrate the ability of oyster larvae to ingest bacteria and assimilate bacterial particulate organic carbon while reducing major sources of error in the transfer of ${ }^{14} \mathrm{C}$ label by processes other than bacterivory.

Acknowledgements. Support for this research was provided by a Markham Award to this project, and by the Oregon Sea Grant, NOAA, grant \# NA 85AA-D-SG095 to Dr Christopher $\mathrm{J}$. Langdon. This research formed part of the author's doctoral thesis submitted to Oregon State University. I am indebted to Dr Langdon for providing laboratory facilities and encouragement, to Dr R. L. Petty, University of California at Santa Barbara, for performing carbon, hydrogen and nitrogen analysis of bacterial cultures, to Drs R. Y. Morita, R. Griffiths, and G. Taghon for helpful discussions, to Drs R. H. Benner and P.A. Montagna, The University of Texas at Austin, for reviewing the manuscript, and to my friends and colleagues, at the Hatfield Marine Science Center, for their support and collaboration.

\section{LITERATURE CITED}

Andersen, P., Sorensen, H. M. (1986). Population dynamics and trophic coupling in pelagic microorganisms in eutrophic coastal waters. Mar. Ecol. Prog. Ser. 33: 99-109

Azam, F., Hodson, R. E. (1977). Size distribution and activity of marine microheterotrophs. Limnol. Oceanogr. 21: 492-501

Babinchak, J., Ukeles, R. (1979). Epifluorescence microscopy, a technique for the study of feeding in Crassostrea virginica veliger larvae. Mar. Biol. 51: 69-76

Baldwin, B. S., Newell, R. I. E. (1991). Omnivorous feeding by planktotrophic larvae of the eastern oyster Crassostrea virginica. Mar. Ecol. Prog. Ser. 78(3): 285-301

Bayne, B. L. (1983). Physiological ecology of marine molluscan larvae. In: Wilbur, K. M. (ed.) The Mollusca. Academic Press, New York, p. 299-343

Berman, T., Nawrocki, M., Taylor, G. T., Karl, D. M. (1987). Nutrient flux between bacteria, bacterivorous nanoplanktonic protists and algae. Mar. microb. Food Webs 2(2): $69-82$

Bratbak, G. (1985). Bacterial biovolume and biomass estimations. Appl, environ. Microbiol. 49(6): 1488-1493

Calow, P., Fletcher, C. R. (1972). A new radiotracer technique involving ${ }^{14} \mathrm{C}$ and ${ }^{51} \mathrm{Cr}$, for estimating the assimilation efficiencies of aquatic, primary consumers. Oecologia 9: $155-170$

Caron, D. A., Davis, P. G., Madin, L. P., Sieburth, J McN (1982). Heterotrophic bacteria and bacterivorous protozoa in oceanic microaggregates. Science 218: 795-797

Chretiennot-Dinet, M.-J. (1982). Production primaire en baie de Concarneau. Relations algues bactéries et filtration différentielle. J. Plankton Res. 4(3): 463-479

Conover, R. J., Francis, V. (1973). The use of radioactive isotopes to measure the transfer of materials in aquatic food chains. Mar. Biol. 18: 272-283

Crisp, D. J., Yule, A. B., White, K. N. (1985). Feeding of oyster larvae: the functional response, energy budget and a 
comparison with mussel larvae. J. mar. biol. Ass. U.K. 65: $759-783$

Decho, A. W., Castenholz, R. W. (1986). Spatial patterns and feeding of meiobenthic harpacticoid copepods in relation to resident microbial flora. Hydrobiologia 131: 87-96

Douillet, P. (1991). Beneficial effects of bacteria on the culture of larvae of the Pacific oyster Crassostrea gigas (Thunberg). Ph.D. thesis, Oregon State University

Douillet, P., Langdon, C. C. (1993). Effects of marine bacteria on the culture of axenic oyster Crassostrea gigas (Thunberg) larvae. Biol. Bull. 184: 36-51

Ducklow, H. W. (1983). Production and fate of bacteria in the oceans. BioSci. 33: 494-501

Fenchel, T. (1982). Ecology of heterotrophic microflagellates. IV. Quantitative occurrence and importance as bacterial consumers. Mar. Ecol. Prog. Ser. 9: 35-42

Ferguson, R. L., Rublee, P. (1976). Contribution of bacteria to standing crop of coastal plankton. Limnol. Oceanogr. 21: $19-27$

Fretter, V., Montgomery, M. C. (1968). The treatment of food by prosobranch veligers. J. mar. Biol. Assoc. U.K. 48: $499-520$

Frikha, M.-G., Linley, E. A. S. (1988/1989). Predation on bacterioplankton in oyster ponds of the Atlantic coast of France. Mar. microb. Food Webs 3(2): 67-78

Fuhrman, J. A. (1981). Influence of method on the apparent size distribution of bacterioplankton cells: epifluorescence microscopy compared to scanning electron microscopy. Mar. Ecol. Prog. Ser. 5: 103-106

Fuhrman, J. A., McManus, G. B. (1984). Do bacteria-sized marine eukaryotes consume significant bacterial production? Science 224: 1257-1260

Gallager, S. M. (1988). Visual observations of particle manipulation during feeding in larvae of a bivalve mollusc. Bull. mar. Sci. 43(3): 344-365

Gallager, S. M., Bricelj, V M., Stoecker, D. K. (1989). Effects of the brown tide alga on growth, feeding physiology and locomotory behavior of scallop larvae (Argopecten irradians). In: Cosper, N. Y E., Bricelj, V. M., Carpenter, E. (eds.) Novel phytoplankton blooms, causes and impacts of recurrent brown tide and other unusual blooms. Coastal and estuarine studies. Springer-Verlag, New York, p. 511-541

Haas, L. W., Webb, K. L. (1979). Nutritional mode of several non-pigmented microflagellates from the York River Estuary, Virginia. J. exp. mar. Biol. Ecol. 39: 125-134

Hobbie, J. E., Daley, R. J., Jasper, S. (1977). Use of Nuclepore filters for counting bacteria by fluorescence microscopy. Appl. environ. Microbiol. 33: 1225

Jeanthon, C., Prieur, D., Cochard, J. C. (1988). Bacteriological survey of antibiotic-treated seawater in a Pecten maximus hatchery. Aquaculture 71: 1-8

Johannes, R. E., Satomi, M. (1967). Measuring organic matter retained by aquatic invertebrates. J. Fish. Res. Bd Can. 24: $2467-2471$

Lampert, W. (1977). Studies on the carbon balance of Daphnia pulex as related to environmental conditions. I. Methodological problems of the use of ${ }^{14} \mathrm{C}$ for the measurement of carbon assimilation. Arch. Hydrobiol. Suppl. 48(3/4): $287-309$

Langdon, C. J. (1983). Growth studies with bacteria-free oyster (Crassostrea gigas) larvae fed on semi-defined artificial diets. Biol. Bull. 164: 227-235

Lee, S., Fuhrman, J. A. (1987). Relationships between biovolume and biomass of naturally derived marine bacterioplankton. Appl. environ. Microbiol. 53(6): 1298-1303

Luria, S. E. (1960). The bacterial protoplasm: composition and organization. In: Gunsalus, I. C., Stanier, R. Y (eds.) The Bacteria, Vol. 1. Academic Press, New York, p. 1-34

Manahan, D. T., Richardson, K. (1983). Competition on the uptake of dissolved organic nutrients by bivalve larvae (Mytilus edulis) and marine bacteria. Mar Biol. 75: 241-247

Mengus, B. (1978). Role des bactéries dans l'alimentation de larves de mollusques bivalves marins, en élevages expérimentaux. Thèse $3^{\mathrm{e}}$ Cycle Oceanogr. Biol., Univ. AixMarseille II

Moriarty, D. J., Pollard, P. C., Hunt, W. G. (1985). Temporal and spatial variation in bacterial production in the water column over a coral reef. Mar. Biol. 85(3): 285-292

Nagata, T. (1986). Carbon and nitrogen content of natural planktonic bacteria. Appl. environ. Microbiol. 52: 28

Nelson, C. L., Siddall, S. E. (1988). Effects of an algal bloom isolate on growth and survival of bay scallop Argopecten irradians larvae. J. Shellfish Res. 7(4): 683-694

Palumbo, A. V., Ferguson, R. L. (1978). Distribution of suspended bacteria in the Newport River Estuary, North Carolina. Estuar. coast. Shelf Sci. 7: 521-529

Palumbo, A. V., Ferguson, R. L., Rublee, P. A. (1984). Size of suspended bacterial cells and association of heterotrophic activity with size fractions of particles in estuarine and coastal waters. Appl. environ. Microbiol. 48(1): 157-164

Pechenik, J. A. (1979). Leakage of ingested carbon by gastropod larvae, and its effect on the calculation of assimilation efficiency. Estuaries 2(1): $45-49$

Pechenik, J. A., Fisher, N. S. (1979). Feeding, assimilation, and growth of mud snail larvae, Nassarius obsoletus (Say), on three different algal diets. J. exp. mar. Biol. Ecol. 38: $57-80$

Peterson, B. J., Hobbie, J. E., Haney, J. F. (1978). Daphnia grazing on natural bacteria. Limnol. Oceanogr. 23(5): $1039-1044$

Porter, K. G., Feig, Y. S. (1980). The use of DAPI for identifying and counting aquatic microflora. Limnol. Oceanogr. 25: $943-948$

Prieur, D. (1981). Les relations entre mollusques bivalves et bactéries héterotrophes en milieu marin. Etude analytique et expérimentale. Thèse Doct. Etat. Sci. Nat., Univ, de Brest

Riemann, B., Nielsen, P., Jeppesen, M., Marcussen, B., Fuhrman, J. A. (1984). Diel changes in bacterial biomass and growth rates in coastal environments, determined by means of thymidine incorporation into DNA, frequency of dividing cells (FDC), and microautoradiography. Mar. Ecol. Prog. Ser 17: 227-235

Rigler, F. H. (1971). Methods for the measurement of assimilation of food by zooplankton. In: Edmondson, W. T., Winberg, G. G. (eds.) A manual on methods for the assessment of secondary productivity in freshwaters. IBP Handbook No. 17. Blackwell, Oxford, p. 264-270

Riisgard, H. V., Randlov, A., Kristensen, P. S. (1980). Rates of water processing, oxygen consumption, and efficiency of particle retention in veligers and young post metamorphic Mytilus edulis. Ophelia 19: 37-47

Rivier, A., Brownlee, D. C., Sheldon, R. W., Rassoulzadegan, F. (1985). Growth of microzooplankton: a comparative study of bacterivorous zooflagellates and ciliates. Mar. microb. Food Webs 1: 51-60

Rivkin, R. B., Bosch, I., Pearse, J. S., Lessard, E. J. (1986). Bacterivory: a novel feeding mode for asteroid larvae. Science 233: 1311-1314

Seiderer, L. J., Newell, R. C., Schultes, K., Robb, F. T., Turley, C. M. (1987). Novel bacteriolytic activity associated with the style microflora of the mussel Mytilus edulis (L.) 
J. exp. mar. Biol. Ecol. 110: 213-224

Sherr, E. B., Sherr, B. F. (1987). High rates of consumption of bacteria by pelagic ciliates. Nature $325: 710-711$

Sieburth, J. MCN., Smetacek, V., Lenz, J. (1978). Pelagic ecosystem structure: heterotrophic compartments of the plankton and their relationships to plankton size fractions. Limnol. Oceanogr. 23(6): 1256-1263

Sokal, R. R., Rohlf, F. J. (1981). Biometry. W. H. Freeman \& Co., San Francisco

Sorokin, J. I. (1966). Carbon-14 method in the study of the nutrition of aquatic animals. Int. Rev. ges. Hydrobiol. 51(2): $209-224$

Sprung, M. (1984). Physiological energetics of mussel larvae (Mytilus edulis). II. Food uptake. Mar. Ecol. Prog. Ser. 17: 295-305

Tracey, G. A., Johnson, P. W., Steele, R. W., Hargraves, P. E., Sieburth, J. MCN. (1988). A shift in photosynthetic picoplankton composition and its effect on bivalve mollusc nutrition: the 1985 'brown tide' in Narragansett Bay, Rhode Island. J. Shellfish Res. 7(4): 671-675

This article was presented by D. K. Stoecker, Cambridge, Maryland, USA
Watson, S. W., Novitsky, H. L., Quinby, H. L., Valois, F. W. (1977). Determination of bacterial number and biomass in the marine environment. Appl. environ. microbiol. 33: 940-946

Williams, P. J. (1981). Incorporation of microheterotrophic processes into the classical paradigm of the planktonic food web. Kiel. Meeresforsch., Sonderh. 5: 1-28

Wilson, C. A., Stevenson, L. H. (1980). The dynamics of the bacterial population associated with a salt marsh. J. exp. mar. Biol. Ecol. 48: 123-138

Wright, R. T., Coffin, R. B., Ersing, C. P., Pearson, I, D. (1982). Field and laboratory measurements of bivalve filtration of natural marine bacterioplankton. Limnol. Oceanogr. 27(1): $91-98$

Zhukova, A. I. (1963). On the quantitative significance of microorganisms in nutrition of aquatic invertebrates. In: Oppenheimer, C. H. (ed.) Symposium on marine microbiology. Charles C. Thomas, Springfield, p. 699-710

Zobell, C. E., Feltham, C. B. (1938). Bacteria as food for certain marine invertebrates. J. mar. Res. 1: 312-327

Manuscript first received: June 3, 1992

Revised version accepted: April 7, 1993 